MUHAMMED YASIN ÇODUR, Ph.D. ${ }^{1}$

(Corresponding author)

E-mail: mycodur@erzurum.edu.tr

AHMET ÜNAL, M.Sc. ${ }^{1}$

E-mail: ahmet.unal@erzurum.edu.tr

${ }^{1}$ Erzurum Technical University

Faculty of Engineering and Architecture

Civil Engineering Department

25070 Erzurum, Turkey
Swarm Intelligence in Transportation Engineering

Preliminary Communication

Submitted: 22 July 2018

Accepted: 5 Feb. 2019

\title{
AN ESTIMATION OF TRANSPORT ENERGY DEMAND IN TURKEY VIA ARTIFICIAL NEURAL NETWORKS
}

\begin{abstract}
The transportation sector accounts for nearly $19 \%$ of total energy consumption in Turkey, where energy demand increases rapidly depending on the economic and human population growth and the increasing number of motor vehicles. Hence, the estimation of future energy demand is of great importance to design, plan and use the transportation systems more efficiently, for which a reliable quantitative estimation is of primary concern. However, the estimation of transport energy demand is a complex task, since various model parameters are interacting with each other. In this study, artificial neural networks were used to estimate the energy demand in transportation sector in Turkey. Gross domestic product, oil prices, population, vehicle- $\mathrm{km}$, ton- $\mathrm{km}$ and passenger-km were selected as parameters by considering the data for the period from 1975 to 2016. Seven models in total were created and analyzed. The best yielding model with the parameters of oil price, population and motor vehicle-km was determined to have the lowest error and the highest $R^{2}$ values. This model was selected to estimate transport energy demand for the years 2020, 2023, 2025 and 2030.
\end{abstract}

\section{KEY WORDS}

artificial neural networks; gross domestic product; transport energy demand; passenger; oil price;

\section{INTRODUCTION}

Socioeconomic development of societies may change individuals' vital activities, thus increasing their energy demand. Energy has turned out to be one of the indispensable sources of countries from past to present. With the onset of the industrialization process after the industrial revolution, energy gained such importance as never seen before in societies' history. There is a direct relationship between the energy consumption or demand rates of nations and their development level and industrialization. Saving energy in its production process is a very important issue to support economic and social development based on country-level planning. Every country has its own priorities and different requirements for energy production, consumption and saving, and this situation increases the importance of energy related planning.

Turkey is located in the northern hemisphere, connecting Asia and Europe. The surface area of the country is $814,578 \mathrm{~km}^{2}, 779,452 \mathrm{~km}^{2}$ of which are too mountainous to settle and $3 \%$ of which is located in the European territory (Thrace), and the rest is in the Asian region called Anatolia. The width of the country that resembles a rectangle is about $550 \mathrm{~km}$ and its length is $1,500 \mathrm{~km}$. The length of the sea borders is $8,333 \mathrm{~km}$ and the land borders are $2,875 \mathrm{~km}$ long. The country has always maintained its importance as a bridge between Europe and Asia. The population of the country is over 81 million. In the industry and services sectors, a total of $100,734,472$ tons of oil equivalent energy (toe) was consumed in 2014 and $86,136,765$ toe was the amount of consumed energy in the industrial sector, whereas the service sector consumed 14,597,707 toe. The largest sectors sharing total energy consumption were electricity generation and distribution, which accounted for $42.4 \%$, the manufacturing industry was responsible for $38.4 \%$, and the transportation and storage sector had a share of $9.5 \%$. Looking at the annual consumption by fuel type, the amount of natural gas consumption was top-ranked in 2014. Lignite coal was consumed to produce 1,641,693 toe, while coal consumption produced a $15,981,137$ toe in the third place. When energy consumption is examined according to sectors, the manufacturing industry had the highest electricity consumption with $78,330,897 \mathrm{MWh}$ in 2014. In the industrial and service sectors, $79.7 \%$ of the energy was consumed for the production of goods and provision of services, and $13.2 \%$ of this amount was consumed for lighting and plugging electrical devices at offices.

The need for new energy sources increases consistently in the developed and developing countries. The transport sector is among the rapidly growing major 
consumers of primary energy production by consuming about one-fifth of the primary energy produced in the world [1]. Along with the increasing population, there has been a serious increase in vehicle ownership. In Turkey, at the end of November 2016, the total number of motor vehicles was 20 million, 53.6\% of which are automobiles [2]. While the population of Turkey was $39,185,637$ in 1975 , this number grew to $78,665,830$ in 2015 [3]. Turkey meets its energy demands primarily from other countries. In other words, seventy-five percent of Turkey's total energy is imported from abroad as natural gas and crude oil. The external energy dependency is seen more clearly in the transportation sector. Turkey aims to establish nuclear power plants in order to reduce the external dependency of energy. In this context, Turkey aims to commission a 10,000 MW nuclear power plant by 2030 . It is known that petroleum products are generally consumed as energy resources that cannot be renewed in the transportation sector. In developed countries, the oil consumption rates in the transport sector are at $70 \%$ [4]. There are two reasons for this high ratio: the first one is the increase in private vehicle use and ownership; the second reason is the tendency in the prices of petroleum products. When it comes to the consumption of oil, the domestic sources of Turkey cannot meet the needs. Turkey's oil dependency rate is around $90 \%$. Turkey has an average consumption of 601,000 barrels of oil and petroleum products per day and 47,000 barrels of total consumption are provided by Turkey's domestic sources, and the remaining 554,000 barrels are imported [5].

It is important to predict the future energy demand by understanding the past period in energy planning studies. Transportation demand increased more than gross domestic product (GDP) in Turkey when national economic parameters are compared to those of the transportation sector. Undoubtedly, transport energy consumption is influenced by many factors (such as age of vehicles, the state of the transport infrastructure, driving style etc.). In this study, transportation energy demand (TED) of Turkey was evaluated. The most relevant parameters that influence transport energy consumption were determined as a result of the evaluation of all relevant factors. Since these factors and their interrelationship are complex, artificial neural networks (ANN) methodology was preferred. The selection of ANN is highly mature for such studies, and several usage examples are provided in the forthcoming section. The novelty of this study is to test various variables to model the TED. Seven ANN models were developed, where the variable sets differentiate considerably, and previous models in the literature with different variables are compared.

\section{LITERATURE REVIEW}

Turkey is one of the largest economies among the Balkan and the Middle East countries. This pertains especially to the field of industry, and the country has experienced major development after the 1960s. The country is the 18th largest economy in the world according to nominal GDP and is a founding member of major economic organizations such as the OECD and G20. While the economies of many European countries have been stagnant due to the crisis in 2008 , Turkey's economy grew by $9.2 \%$ in 2010 and $8.5 \%$ in 2011 [6]. It is a well-known fact that the development of the economy increases the total energy demand. While this demand for energy in 1990 was 52.9 million tons oil equivalent (mtoe), it reached up to 120.29 mtoe in 2013. While the total energy demand provided by the domestic producers in 1990 was 48\%, this ratio decreased to $28.5 \%$ in 2013 [7]. When examining the energy consumption values from the sectoral perspective, $57.7 \%$ of the total final energy consumption in 2014 was recorded in the industrial and manufacturing sectors, $19.3 \%$ in the transportation sector and $4.7 \%$ in the construction sector. When annual fuel consumption values were examined, the largest natural gas amount was consumed in 2014. Lignite coal was consumed in the quantity of $16,416,093$ toe, while coal consumption was ranked third with 15,981,137 toe [8]. This economic development will undoubtedly increase the demand for energy in the coming years. Turkey's economic development in the past 40 years has caused GDP, vehicle-km and population values to rise. These and similar situations attracted the attention of many scientists and therefore they tried to predict the future energy demands with different modeling technique studies. Energy demand is estimated using different models in the literature.

Murat and Ceylan established models to predict energy demand in transportation using ANN. They used gross national product (GNP), population and vehicle-km, along with historical energy data available from 1970 to 2001 . The ANN models reflect the fluctuation in historical data for both dependent and independent variables [9]. Haldenbilen and Ceylan created a model using a genetic algorithm. This model was used to estimate the amount of energy demand in the transportation sector in Turkey by 2020 using population, GDP, and vehicle-km data [10]. Canyurt et al. estimated the energy demand in the transportation sector of Turkey by taking advantage of the genetic algorithm approach [11]. Ediger and Çamdalı investigated exergy and energy efficiencies in Turkish transportation sector. They evaluated the energy efficiency coefficients in the transportation sector using data from eight transport modes between 1988 and 2004. They used 
ton-of-oil-equivalent as an energy consumption unit, as well as consumption data for coal, lignite, gasoline, electricity and natural gas fuels to study the amount of fuel consumed [12].

Utlu and Hepbaşlı evaluated energy utilization efficiency in the Turkish transportation sector between 2000 and 2020 using the energy and exergy analysis method. They evaluated four modes of transportation in their study (road, air, rail and sea), comparing the energy usage coefficients in the sector between 2000 and 2020 [13]. Saidur et al. made energy consumption estimations for four modes of transport in Malaysia. They used data between 1995 and 2003 in their studies [14]. Wohlgemuth worked on world transport demand modeling. He divided the world into 13 regions and used data on the energy demands of those regions from 1971 to 1993 [15].

Geem modeled the TED of South Korea using ANNs. Population, oil prices, number of vehicle registrations and passenger transport amount were used as variables in the study. ANNs with multiple linear regression are compared with four different scenarios. ANNs are often used as artificial intelligence techniques to predict energy demand. Many authors have been working on modeling with different variables without estimating different types of energy demand [16]. Ceylan et al. made a modeling study to estimate Turkey's transportation energy demand by taking advantage of the metaheuristic approach. They used GDP, population and vehicle-km data in their studies. The data used in the study for the period 1970-2005 were obtained from the Central Bank of Turkey. They estimated energy demand using three different approaches: linear, quadratic and exponential. They found that the exponential form gave the most favorable result in these three approach forms [17]. Limanond et al. worked to estimate the energy demand in Thailand's transport sector. They used ANN and log linear regression model on data from 1989-2008, which they obtained from government agencies [18]. Bose and Srivinasachary investigated the factors affecting energy consumption in the transportation sector in Delhi. They aimed to estimate the energy demand in the passenger transport sector of Delhi, using the Long Range Energy Alternatives Planning (LEAP) software and creating 5 different scenarios [19]. Shabbir and Ahmad studied monitoring urban transport air pollution and energy demand in Ravalpindi and Islamabad using the LEAP model. They projected energy demand in the transport sector in 2030 for two cities by creating four different scenarios in their work [20]. Başkan et al. improved estimation models for Turkey's TED using ant colony optimization. Their best model underestimated the TED of Turkey by $28 \%$ as compared to the Ministry of Energy and
Natural Resources projection for 2025 [21]. The population, number of vehicle registrations, total annual vehicle-km, gross product, oil prices, import, export, gross domestic and national product, urbanization rate, passenger turnover and freight turnover, as well as socio-economic and transport related indicators data were used in the modeling studies of TED [22, 23].

ANNs can be described as computer systems that are developed to derive and learn new information by learning to acquire properties of the human brain. ANNs began with the aim to explore the science of neurobiology and to apply the information learned in this subject on computers. ANNs are a class of flexible nonlinear models that can figure out samples adaptively from the data. The advantage of ANNs with respect to the other models is their ability of modeling a multivariable problem given by the complex relationships between the variables. In addition, ANNs can extract the implicit non-linear relationships among these variables by means of "learning" with training data [24]. There are many successful studies to estimate the energy demand in the transport sector [24, 25]. Although many models are proposed in different types, the most popular one related to energy demand in transport is the feedforward network model type. In the ANN model, independent variables are called the input, and the dependent variable is called the output. The input significance chart demonstrates the notional significance of each input column. The input column significance is computed as degradation in network performance after the input is removed and not used by the network [26]. ANNs comprise a lot of nodes that run in parallel and connect them all through connecting synapses. The greatest advantage of a neural network is its ability to model a complex nonlinear relationship without prior assumptions of the nature of the relationship like a block box [23]. ANNs have been successfully applied for solving complex problems in different fields of application, including pattern identification, recognition, speech, vision, control system and classification. Today, ANNs can be trained to solve problems that are difficult for conventional computers or human beings. ANNs, in other words, overcome the limitations of the conventional approach by extracting the desired information directly from the data. The fundamental processing element of a neural network is a neuron. Basically, a biological neuron receives inputs from other sources, combines them in some way, performs generally a nonlinear operation on the result, and then outputs the final result.

ANNs are frequently used in models related to estimation studies. The main advantages of ANNs are that they have error tolerance, work with incomplete 
data and learn by using examples. In this paper, TED is estimated by using seven different models. One of the important features of this study is that the estimated power of the model found by incorporating oil prices into the model is greater than that in previous studies.

\section{DATA AND METHODOLOGY}

\subsection{Data collection}

Candidate parameters were selected and relevant periodical data were collected from different government agencies. One of the most important variables collected from the Turkish Statistical Institute is the amount of transport energy demand [5]. Other variables, such as vehicle-km, ton-km and passenger-km, were gathered from the General Directorate of Turkish Highways [2]. GDP and population values were obtained from the World Bank (WB) [3]. Table 1 explains the rationale behind the selection of these variables and the data sources.

GDP: It is the measure of a country's total goods and services it produces for a given year.

Population: The number of people living in a certain region with a border.

Vehicle-km: The unit of traffic obtained by the movement of one motorized vehicle within one kilometer.

Ton-km: The unit of traffic obtained by transporting one ton of load over one kilometer distance.

Table 1 - Parameter use rationale
Passenger-km: The unit of measurement representing the transport of one passenger by a defined mode of transport (road, rail, air, sea, inland waterways etc.) over one kilometer.

Oil price: Oil price is one of the important indicators in terms of global and national economic performance.

The data about the above stated parameters are shown in details in Table 2. Transport energy consumption has increased from 5,148 to 24,740 mtoe, resulting in the equivalent of a 4.80 times increase over the 40 years. During the same period, the national data in terms of GDP grew 16.80 times.

The resulting correlation matrix for transport energy demand is given in Table 3. There is a high correlation between the independent variables and the dependent variable. According to the correlation analysis, the most important parameters are vehicle-km and passenger-km values. Although the contribution of oil price is slightly lower than that of other variables, it may be better to include it during the modeling process because of its positive effect on the dependent variable.

Since the Paris Treaty, world countries have been increasingly interested in expanding the use of electric vehicles so as to reduce the effects of greenhouse gas emissions. Electric vehicles are operated by supplying power from a battery and an external power supply. The number of electric vehicles increases consistently, and it reached 2 million at the end of 2016. In the scope of the methodology of the present study, the use of electric vehicles is thought to affect the amount of

\begin{tabular}{||l|l|l||}
\hline Variable & \multicolumn{1}{|c|}{ Source } & \multicolumn{1}{c|}{ The reason for using this variable } \\
\hline \hline GDP & $\begin{array}{l}\text { Turkish Statistical } \\
\text { Institute (TSI) }\end{array}$ & $\begin{array}{l}\text { The data are harmonized considering the growth rates given by the TSI. GDP is } \\
\text { selected as an independent variable. It is assumed that this change will affect } \\
\text { energy demand as the value of the country changes depending on its economic } \\
\text { growth. }\end{array}$ \\
\hline Population & World Bank & $\begin{array}{l}\text { The amount of population is undoubtedly affecting the amount of energy countries } \\
\text { need. The reason for increase in energy consumption can be linked to increase in } \\
\text { the population of Turkey. For this reason, population values was chosen as one of } \\
\text { the independent variables. }\end{array}$ \\
\hline Vehicle-km & $\begin{array}{l}\text { General Directorate } \\
\text { of Turkish Highways } \\
\text { (GDTH) }\end{array}$ & $\begin{array}{l}\text { Vehicle-km has been chosen since it contributes to the knowledge of a country's } \\
\text { transportation network and the preferences of people in the country for transpor- } \\
\text { tation. }\end{array}$ \\
\hline Ton-km & GDTH & $\begin{array}{l}\text { Ton-km was chosen as an independent variable, especially since it is an important } \\
\text { parameter to understand the weight of the transportation sector within the } \\
\text { country. }\end{array}$ \\
\hline Passenger-km & GDTH & $\begin{array}{l}\text { The passenger-km values are chosen as independent variables. This is because } \\
\text { people in the country give information about travel conditions. }\end{array}$ \\
\hline Oil price & TSI & $\begin{array}{l}\text { Oil price level is one of the determinants of people's choices in transportation. } \\
\text { Increasing oil prices causes people to reduce energy requirements for } \\
\text { transportation. }\end{array}$ \\
\hline
\end{tabular}


Table 2 - Observed historical data / transport energy and various indicators in Turkey

\begin{tabular}{|c|c|c|c|c|c|c|c|}
\hline Years & $\operatorname{GDP}\left(10^{6} \$\right)$ & Population & Ton-km & Vehicle-km & Passenger-km & $\begin{array}{l}\text { Oil price } \\
(\$)\end{array}$ & $\begin{array}{l}\text { Transport energy } \\
\text { (mtoe) }\end{array}$ \\
\hline 1975 & 44,634 & $39,185,637$ & 29,424 & 13,432 & 68,395 & 10.9 & 5,148 \\
\hline 1980 & 68,789 & $43,905,790$ & 37,507 & 15,343 & 73,127 & 33 & 5,230 \\
\hline 1985 & 67,235 & $49,178,079$ & 45,634 & 18,667 & 91,566 & 29.9 & 6,195 \\
\hline 1990 & 150,676 & $53,994,605$ & 65,710 & 27,041 & 134,991 & 20.7 & 8,723 \\
\hline 1991 & 150,028 & $54,909,508$ & 61,969 & 26,056 & 131,029 & 23.2 & 8,304 \\
\hline 1992 & 158,459 & $55,811,134$ & 67,704 & 28,514 & 142,173 & 17 & 8,545 \\
\hline 1993 & 180,170 & $56,707,454$ & 97,843 & 30,807 & 146,029 & 16.6 & 10,419 \\
\hline 1994 & 130,690 & $57,608,769$ & 95,020 & 31,251 & 140,743 & 13.4 & 9,907 \\
\hline 1995 & 169,486 & $58,522,320$ & 112,515 & 34,833 & 155,202 & 16.6 & 11,066 \\
\hline 1996 & 181,476 & $59,451,488$ & 135,781 & 41,015 & 167,871 & 18.3 & 11,777 \\
\hline 1997 & 189,835 & $60,394,104$ & 139,789 & 46,384 & 180,967 & 23.4 & 11,338 \\
\hline 1998 & 269,287 & $61,344,874$ & 152,210 & 49,947 & 186,159 & 15.1 & 10,760 \\
\hline 1999 & 249,751 & $62,295,617$ & 150,974 & 49,866 & 175,236 & 10.3 & 11,350 \\
\hline 2000 & 266,568 & $63,240,157$ & 161,552 & 56,151 & 185,681 & 24.5 & 12,007 \\
\hline 2001 & 196,005 & $64,182,694$ & 151,421 & 52,631 & 168,211 & 23.4 & 11,999 \\
\hline 2002 & 232,535 & $65,125,766$ & 150,912 & 51,664 & 163,327 & 18.6 & 11,404 \\
\hline 2003 & 303,005 & $66,060,121$ & 152,163 & 52,349 & 164,311 & 27.7 & 12,395 \\
\hline 2004 & 392,166 & $66,973,561$ & 156,853 & 57,767 & 174,312 & 30.4 & 13,774 \\
\hline 2005 & 482,980 & $67,860,617$ & 166,831 & 61,129 & 182,152 & 38.3 & 13,849 \\
\hline 2006 & 530,900 & $68,704,721$ & 177,399 & 64,577 & 187,593 & 57.2 & 14,982 \\
\hline 2007 & 647,140 & $69,515,492$ & 181,330 & 69,609 & 209,115 & 71 & 17,265 \\
\hline 2008 & 730,325 & $70,344,357$ & 181,935 & 69,771 & 206,098 & 97 & 15,976 \\
\hline 2009 & 614,570 & $71,261,307$ & 176,455 & 72,432 & 212,464 & 62 & 15,895 \\
\hline 2010 & 731,145 & $72,310,416$ & 190,365 & 80,124 & 226,913 & 79 & 15,136 \\
\hline 2011 & 774,775 & $73,517,002$ & 203,072 & 85,495 & 242,265 & 104 & 15,852 \\
\hline 2012 & 788,863 & $74,849,187$ & 216,123 & 93,989 & 258,874 & 121.7 & 20,753 \\
\hline 2013 & 823,257 & $76,223,639$ & 224,048 & 99,431 & 268,178 & 112.5 & 22,772 \\
\hline 2014 & 798,782 & $77,523,788$ & 234,492 & 102,988 & 276,073 & 106.89 & 24,351 \\
\hline 2015 & 717,880 & $78,665,830$ & 244,329 & 113,274 & 290,734 & 51.1 & 24,740 \\
\hline 2016 & 857,700 & $79,814,871$ & 253,139 & 119,671 & 300,852 & 60.2 & 24,951 \\
\hline
\end{tabular}

Table 3 - The correlation matrices of the variables

\begin{tabular}{||l|c|c|c|c|c|c|c||}
\hline & GDP & Population & Ton-km & Vehicle-km & Passenger-km & Oil price & Energy \\
\hline \hline GDP & 1 & & & & & & \\
\hline Population & 0.9046 & 1 & & & & & \\
\hline Vehicle-km & 0.8928 & 0.9731 & 1 & & & & \\
\hline Passenger-km & 0.9409 & 0.9528 & 0.9671 & 1 & & & \\
\hline Oil price & 0.8996 & 0.9606 & 0.9640 & 0.9779 & 1 & & \\
\hline Energy & 0.9144 & 0.9299 & 0.9365 & 0.9752 & 0.9655 & 0.7458 & 1 \\
\hline
\end{tabular}


energy demand. However, total number of electric vehicles in Turkey was 426 in 2016, and such a small number is omitted in the modeling stage.

\subsection{Artificial neural network modeling}

Before constructing a neural network model for the transport energy demand, non-dimensional groups that can be used as the input and target parameters need to be selected. The variables used in the previous studies and the correlation matrix were taken into account and the input variables were determined for different models. In the pre-processing of the network, both input and output variables were normalized within the range 0-1 using a minimax algorithm. Table 4 shows the parameters used when creating ANN models. Then the best networks were selected in the design part.

The training procedure is the most important part of the ANN modeling. The model was developed, and $70 \%$ of data were used as training data, $15 \%$ of data were used as testing data and $15 \%$ of data were used as validation data. The Levenberg-Marquardt algorithm was used as a training algorithm in the ANN models.

$Y=f_{2}\left\{\left[W_{2}\right] f_{1}\left[\left[W_{1}\right]\left[\begin{array}{c}\text { GDP } \\ \text { Population } \\ \text { Section length } \\ \text { Vehicle }-k m \\ \text { Ton }-k m \\ \text { Passenger }-k m \\ \text { Oil price }\end{array}\right]\left[+b_{1}\right]\right]\left[+b_{2}\right]\right\}$

Table 4 - Creating an ANN network

\begin{tabular}{||l|c||}
\hline \multicolumn{1}{|c|}{ Network Type } & $\begin{array}{c}\text { Feedforward back } \\
\text { propagation }\end{array}$ \\
\hline \hline Training function & TRAINLM \\
\hline Adaption learning function & LEARNGDM \\
\hline Performance function & Mean squared error \\
\hline Transfer function & TANSIG \\
\hline
\end{tabular}

In Equation 1, $Y$ is the transport energy demand, $W_{1}$ and $W_{2}$ are weight matrices, and $b_{1}$ and $b_{2}$ are bias vectors. The effectiveness of the back-propagation training algorithm depends on the number of neurons in the hidden layer; various numbers of neurons (ranging from 1 to 29) in the hidden layer were tested.

Hidden nodes with appropriate nonlinear transfer functions were utilized to process the information obtained by the input nodes. For this study, seven models with different variables were established. General information about the data used and model structures in the models is given in Table 5.

\section{RESULTS}

Seven different models were set up to estimate the ANN models and the model which is the closest to real values is to be used for estimating the future energy demand in the transport sector. Figure 1 shows the analysis results of the established seven different ANN models and the scatter plot of the output and target values. According to this figure, model 1 provides the best fitting of the data, which have the highest correlation ratio and the coefficient of determination $\left(R^{2}\right)$. Therefore, model 1 was used for transport energy demand estimation.

By comparing these seven different models, the error parameters were calculated and considered in the analysis. The difference between the measured or inferred value of a quantity is called absolute error (AE). Root mean square error (RMSE) is also known as the quadratic average, which is a statistical measure for the quantities of change. RMSE is very commonly used and serves as an excellent general-purpose error metric for numerical predictions. Compared to the mean absolute error, RMSE amplifies and severely punishes large errors. Mean squared error (MSE) shows how close a regression line is to a set of points. This is done by taking the distances from the points to the regression line and squaring them. In statistics, the mean absolute error (MAE) is a quantity used to measure how close forecasts or predictions are to the eventual outcomes. The mean absolute percent error

Table 5 - Variables used in the models

\begin{tabular}{|c|c|c|c|}
\hline & Variables used & Model structure & Output \\
\hline Model 1 & Oil price, population, vehicle-km & $3-6-1$ & \multirow{7}{*}{$\begin{array}{c}\text { Transport energy } \\
\text { demand }\end{array}$} \\
\hline Model 2 & Oil price, population, passenger-km & $3-5-1$ & \\
\hline Model 3 & Oil price, population, ton-km & $3-6-1$ & \\
\hline Model 4 & GDP, population, vehicle-km & 3-3-1 & \\
\hline Model 5 & GDP, population, passenger-km & $3-3-1$ & \\
\hline Model 6 & GDP, population, ton-km & $3-4-1$ & \\
\hline Model 7 & GDP, oil price, population, ton-km & $4-10-1$ & \\
\hline
\end{tabular}




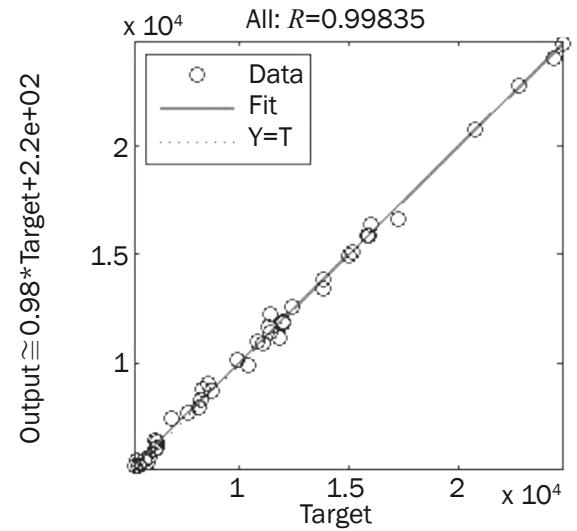

a) Model 1

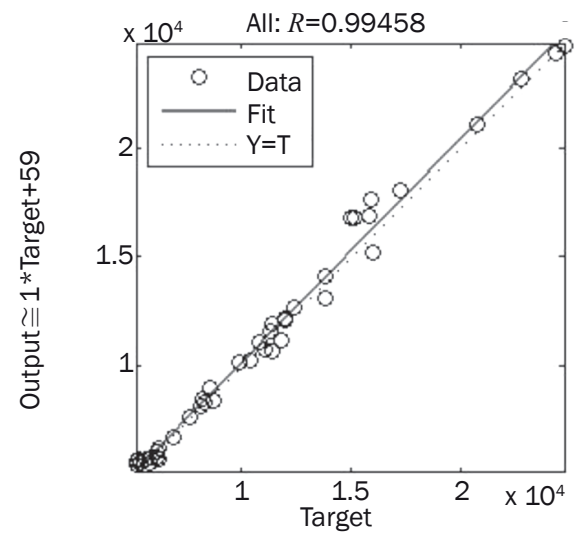

c) Model 3

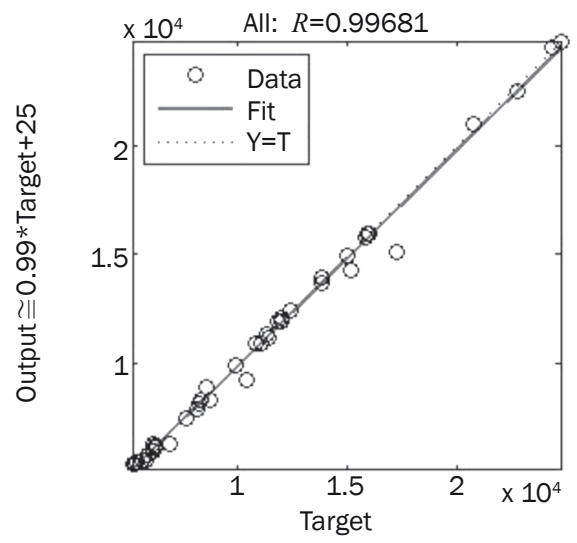

e) Model 5

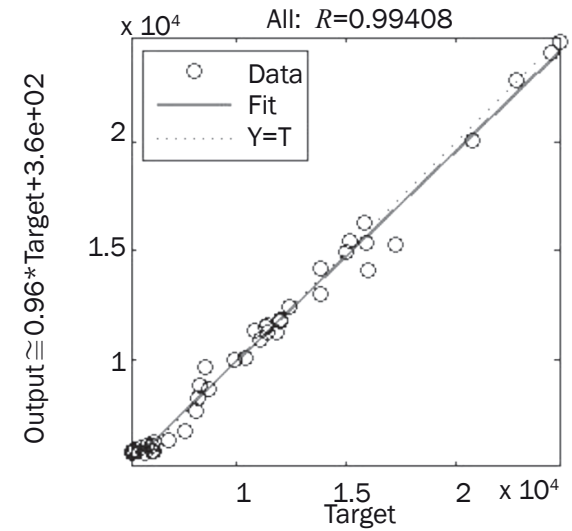

b) Model 2

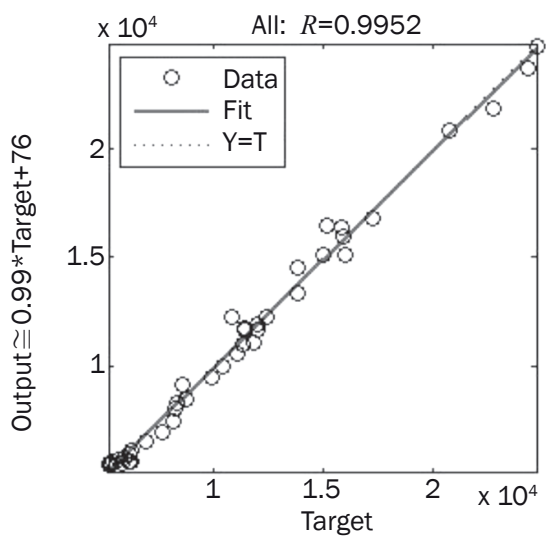

d) Model 4

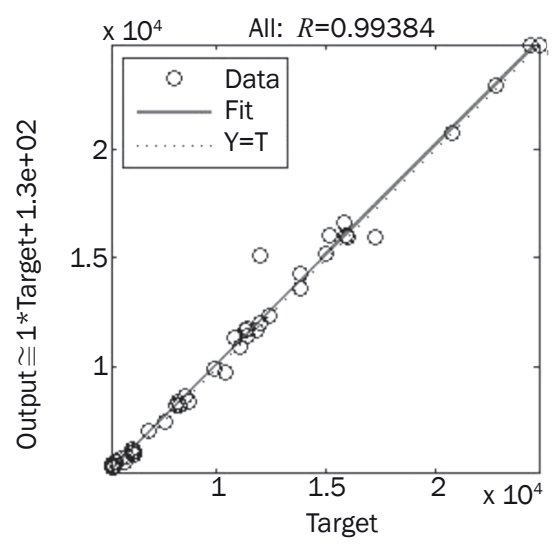

f) Model 6

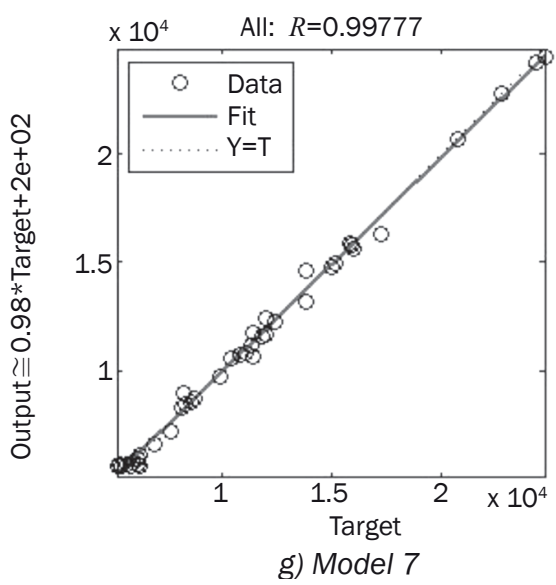

Figure 1 - TED for ANN models 
(MAPE) measures the size of the error in percentage terms. It is calculated as the average of the unsigned percentage error.

As mentioned above, the energy demand in the Turkish transportation sector was estimated using the ANN models, and the best result was achieved with the ANN 1 model. The equations used in the model error calculations are presented below (Equations 2-8) [27].

$$
\begin{aligned}
& A E=\left|E_{o b s}-E_{\text {pre }}\right| \\
& A P E=\left|\frac{E_{o b s}-E_{\text {pre }}}{E_{o b s}}\right| \\
& R^{2}=1-\frac{\sum_{i=1}^{n} A E^{2}}{\sum_{i=1}^{n}\left(E_{o b s}-\overline{E_{o b s}}\right)^{2}} \\
& R M S E=\left(\frac{\sum_{i=1}^{n} A E^{2}}{n}\right)^{0.5} \\
& M A E=\frac{1}{n} \sum_{i=1}^{n} A E \\
& M A P E=\frac{1}{n-1} \sum_{i=2}^{n} A P E \\
& M S E=\frac{\sum_{i=1}^{n} A E^{2}}{n}
\end{aligned}
$$

Table 6 summarizes the error values of the models. When the minimum error rates and high $R^{2}$ values are taken into consideration, it can be seen that model 1 is the most accurate prediction model.
Distribution of transportation energy demand according to years is given in Figure 2. The observed values of the seven models established with ANN, and their relation to the results is also shown.

\section{Estimating and comparing Turkey's transport energy demand}

In order to estimate the future demand for transport energy correctly, it is first necessary to estimate the parameters strongly affecting the model. A reliable estimation of TED is based on the accurate prediction of effective model parameters (i.e., GDP, oil price, population, passenger-km, ton-km and vehicle-km). In this study, seven different models have been established and the energy demand values of the transportation sector in Turkey over the next 15 years have been estimated. It can be seen that the most accurate estimation among these seven models studied was done by model 1 . Examining the model 1 results shows that the rate of population increase is 7.82 per minute. The average oil price growth rate is $7 \%$. Table 7 shows the estimated TED values and the oil price, population, and vehicle-km values used to carry out this estimation. The population will reach 88 million, oil price $94.52 \$ /$ ton and vehicle-km 190 million by 2030 .

In Murat and Ceylan's study the transportation energy demand is estimated by creating two different models in Turkey, called the M\&C Model 1 and M\&C Model 2. In their first model, the maximum growth rate of the population is taken into account as $0.14 \%$. The average GNP growth rate is estimated at $4 \%$, and the increase in vehicle-km is estimated at $7 \%$. The pop-

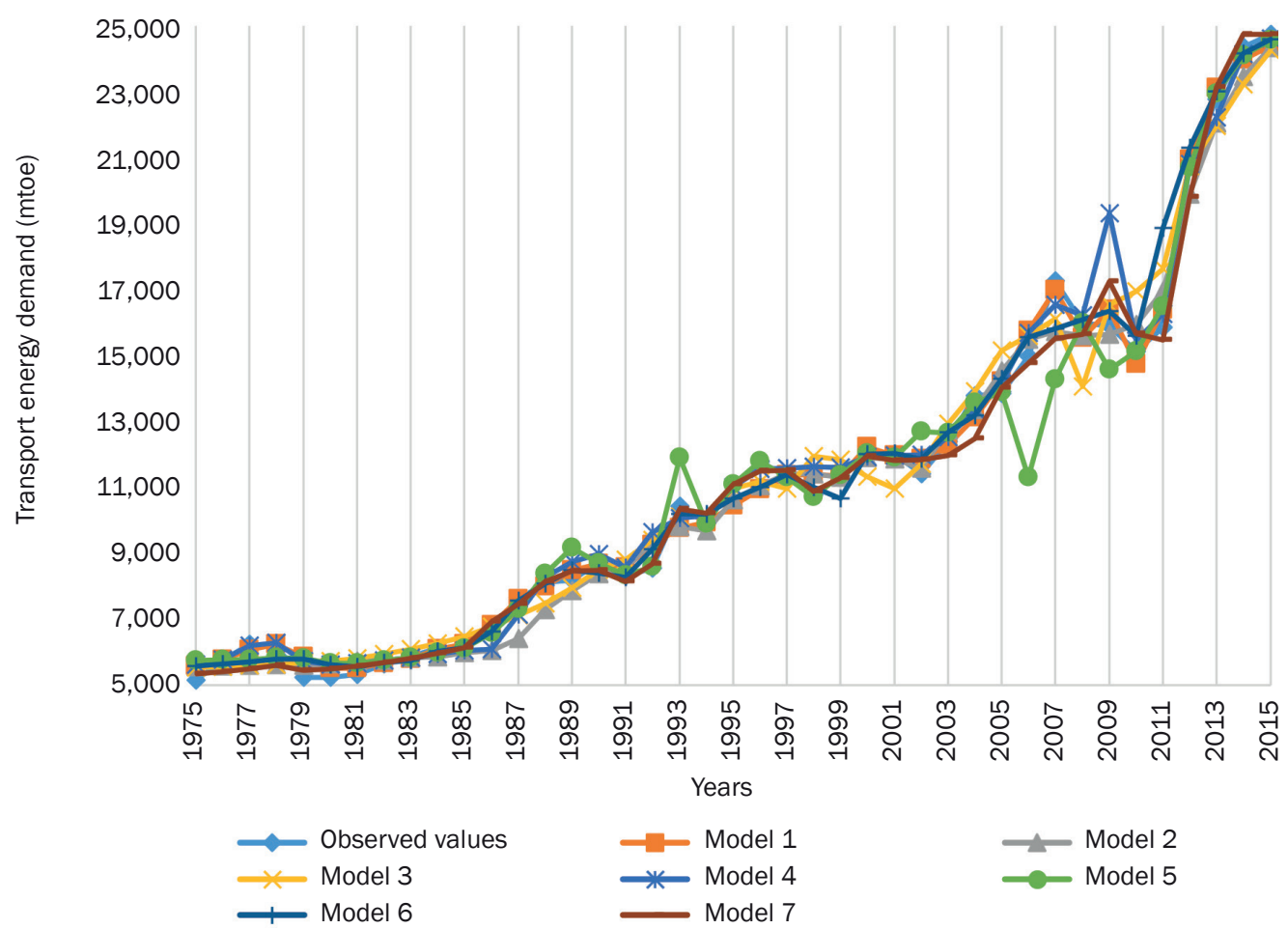

Figure 2 - Transport energy demand 
Table 6 - Error values for seven different TED estimation models

\begin{tabular}{||l|c|c|c|c|c|c|c||}
\hline & Model 1 & Model 2 & Model 3 & Model 4 & Model 5 & Model 6 & Model 7 \\
\hline \hline$R^{2}$ & 0.996702 & 0.988195 & 0.98918 & 0.990423 & 0.993630 & 0.98771 & 0.99554 \\
\hline$R M S E$ & 0.039448 & 0.059422 & 0.051797 & 0.06552 & 0.057167 & 0.675169 & 0.153098 \\
\hline$M A E$ & 301.0301 & 490.8123 & 394.3331 & 603.4895 & 400.8166 & 755.897 & 621.5234 \\
\hline$M A P E$ & 0.029752 & 0.050125 & 0.03812 & 0.057756 & 0.040432 & 0.533395 & 0.060625 \\
\hline$M S E$ & 0.001556 & 0.003531 & 0.002683 & 0.004293 & 0.003268 & 0.455854 & 0.023439 \\
\hline
\end{tabular}

Table 7 - Forecasted TED results for Model 1

\begin{tabular}{||c|c|c|c|c||}
\hline Years & Oil price (\$) & Population & Vehicle-km & Forecasted TED \\
\hline \hline 2020 & 74.82 & $82,076,788$ & 130,612 & 24,172 \\
\hline 2023 & 82.28 & $84,247,088$ & 147,227 & 24,237 \\
\hline 2025 & 86.23 & $85,569,125$ & 158,927 & 24,279 \\
\hline 2030 & 94.52 & $88,427,604$ & 190,360 & 24,398 \\
\hline
\end{tabular}

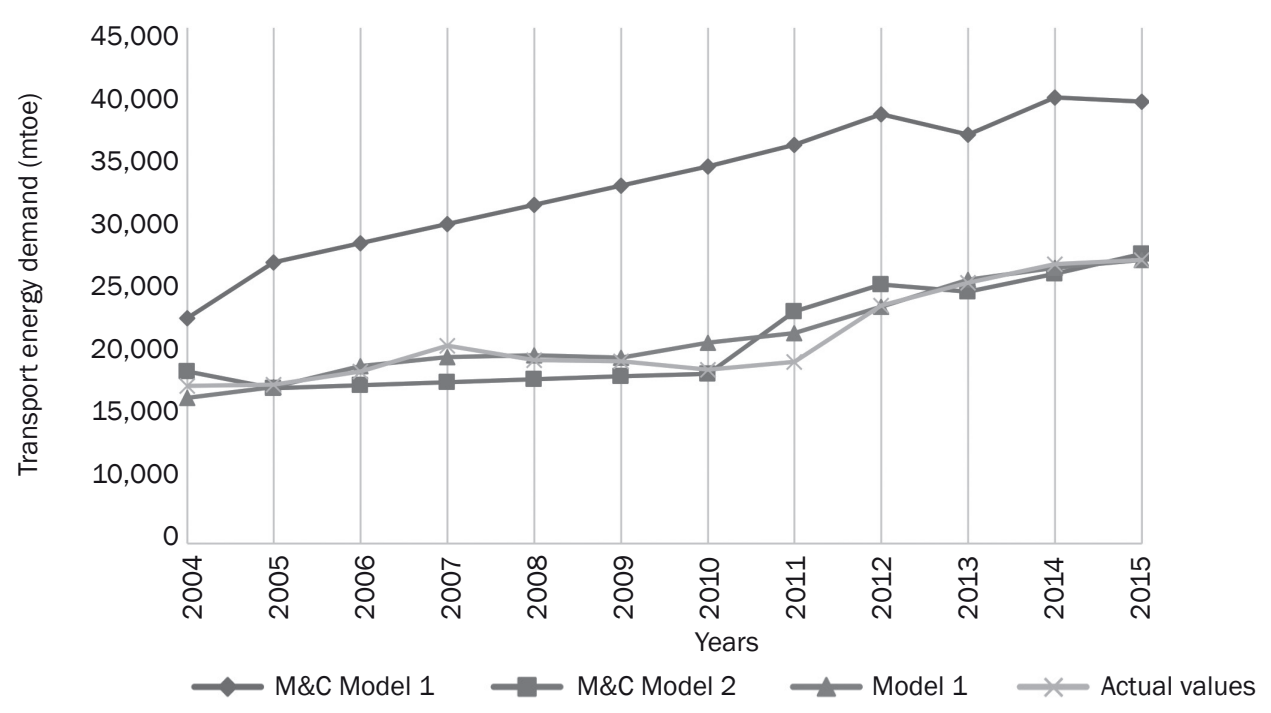

Figure 3 - Comparison of the models for TED

ulation will reach 96 million, the GNP will amount to about $426 \times 10^{9} \$$ and the vehicle-km value estimate is 85 million for 2020. The population increases as the simple growth rate at $1.4 \%$, the GNP and vehicle-km are forecasted under two cases. In Case I, the GNP and vehicle-km are projected using time series (TS), and in Case II they are forecasted using the ANN [9].

Model 1 is compared with these two M\&C models and the observed values in this study. The results are given in Figure 3. It can be clearly seen that model 1 is closer than the other two models to the actual values.

\section{CONCLUSIONS}

Developed or developing countries need energy in every sector, especially industry. It is obvious that energy is an important parameter reflecting the socioeconomic development level of countries. In Turkey, especially in the last 15 years, industrialization has recorded breakthroughs to catch up with state- of-the-art technologies, and urbanization attempts have also increased energy demand, hand in hand with the population growth. Since the energy sector is a strategic area, it is necessary to approach its issues from a strategic point of view. Energy strategies created solely to meet demand in the energy sector will give positive results only in the short term and will not be effective in the long term.

Turkey is largely dependent on imports in terms of primary energy resources. There is no doubt that the increase in Turkey's population has effects on the increase in vehicle ownership, which in turn increases the energy demand in the transportation sector. Approximately $25 \%$ of the total energy consumed in Turkey is used in the transport sector. These increases in energy consumption values indicate the importance of energy demand forecasting for managers' future planning. The results of the models presented in this study can be used by policymakers as a guide for future transportation energy plans in Turkey. 
This study will be particularly useful for countries that import majority of their energy from abroad, such as Turkey. In addition to creation of realistic plans for energy use, this work will contribute to the correct use of resources for other countries in the world that use solar power. On the other hand, appropriate modeling studies on energy demand lead governments to make strategic plans and make the use of energy sources more effective.

\section{MUHAMMED YASIN ÇODUR,Ph.D. ${ }^{1}$}

E-mail: mycodur@erzurum.edu.tr

AHMET ÜNAL,MSc. ${ }^{1}$

E-mail: ahmet.unal@erzurum.edu.tr

${ }^{1}$ Erzurum Teknik Üniversitesi

İnşaat Mühendisliği Bölümü

Erzurum, 25200, Türkiye

\section{TÜRKIYE'DE ULASSTIRMA ENERJISI TALEBININ YAPAY SINIR AĞLARI ILE TAHMINI}

\section{ÖZET}

Ekonomik ve nüfus artışına ve artan motorlu taşıt sayısına bağlı olarak enerji talebinin hızla arttığı Türkiye'de ulaştırma sektörü toplam enerji tüketiminin yaklaşık \%19'unu olușturmaktadır. Bu sebepten dolayı gelecekteki enerji talebinin güvenilir kantitatif tahmini; ulaştırma sistemlerinin daha verimli bir şekilde tasarlanması, planlanması ve kullanılması için büyük önem taşımaktadır. Ancak ulaştırma enerjisi talebinin tahmini çeşitli model parametrelerinin birbiriyle etkileşime girmesi nedeniyle karmaşık bir iştir. Bu çalışmada Türkiye'de ulaștırma sektöründeki enerji talebin tahmin etmek için yapay sinir ağları kullanılmıştır. Gayri safi yurtiçi hasıla, petrol fiyatları, nüfus, taşıt-km, ton-km ve yolcu-km kavramlarının 1975'den 2016'ya kadar olan değerleri göz önüne alınarak parametre olarak seçilmişlerdir. Toplamda yedi model oluşturulmuş ve analiz edilmiştir. Petrol fiyatı, nüfus ve tassıt-km parametrelerine sahip en uygun modelin en düşük hata ve en yüksek $R^{2}$ değerine sahip olduğu belirlenmiştir. Bu model 2020, 2023, 2025 ve 2030 yıllar ulaştırma enerjisi talebini tahmin etmek için seçilmiştir.

\section{ANAHTAR KELIMELER}

yapay sinir ağları; gayri safi yurtiçi hasıla; ulaştırma enerji talebi; yolcu; petrol fiyatı;

\section{REFERENCES}

[1] Asmann D, Sieber Niklas. Transport in Developing Countries: Renewable Energy Versus Energy Reduction. Transport Reviews. 2005;25(6): 719-738.

[2] General Directorate of Turkish Highways (GDTH). Annual Statistics of Turkish Highways; 2016.

[3] WorldBankData; 2015. Available from: https://data. worldbank.org/indicator/SP.POP.TOTL?locations=TR [Accessed 20 October 2018].

[4] Solak AO. Reducing Energy Consumption of Transportation Sector in Turkey: A Scenario Approach. Journal of Economic and Social Research. 2013;9(1): 125-140.

[5] Turkish Statistical Institute (TSI); 2015. Available from:
http://www.turkstat.gov.tr/PreTabloArama.do [Accessed 10 February 2018].

[6] Deutschland Turkey Industry; 2015. Available from: http://www.dtr-ihk.de/tr/ekonomik-veriler/ ekonomi-raporlari/gtai-wirtschaftsbericht-tuerkei -2015 [Accessed 14 February 2018].

[7] The Ministry of Energy and Natural Resources (MENR); 2013. Available from: http://www.enerji.gov.tr/en-US/ Mainpage [Accessed 14 March 2018].

[8] Turkish Statistical Institute (TSI); 2016. Available from:http://www.turkstat.gov.tr[Accessed 7 February 2018].

[9] Murat ŞY, Ceylan H. Use of Artificial Neural Networks for Transport Energy Demand Modeling. Energy Policy. 2016;34: 3165-3172.

[10] Haldenbilen S, Ceylan H. Genetic Algorithm Approach to Estimate Transport Energy Demand in Turkey. Energy Policy. 2005;33: 89-98.

[11] Canyurt EO, Ceylan H, Öztürk HK, Hepbaşlı A. Energy Demand Estimation Based on Two-different Genetic Algorithm Approaches. Energy Sources. 2004;26: 1313-1320.

[12] Ediger VŞ, Çamdalı, Ü. Energy and Exergy Efficiencies in Turkish Transportation Sector. Energy Policy. 2007;35: 1238-1244.

[13] Utlu Z, Hepbaşlı, A. Assessment of the Energy Utilization Efficiency in the Turkish Transportation Sector Between 2000 and 2020 Using Energy and Exergy Analysis Method. Energy Policy. 2006;34(13): 1611-1618.

[14] Saidur R, Sattara MA, Masjukia HH, Ahmed S, Hashim $U$. An Estimation of the Energy and Exergy Efficiencies for the Energy Resources Consumption in the Transportation Sector in Malaysia. Energy Policy. 2007;35: 4018-4026.

[15] Wohlgemuth N. World Transport Energy Demand Modeling: Methodology and Elasticities. Energy Policy. 1997; 25(14-15): 1109-1119.

[16] Geem WZ. Transport Energy Demand Modeling of South Korea Using Artificial Neural Network. Energy Policy. 2011;39: 4644-2050.

[17] Ceylan H, Ceylan H, Haldenbilen S, Başkan O. Transport Energy Modeling with Meta-heuristic Harmony Search Algorithm, an Application to Turkey. Energy Policy. 2008;36: 2527-2535.

[18] Limanond T, Jommonkwao S, Srikaew A. Projection of Future Transport Energy Demand of Thailand. Energy Policy. 2011;39: 2754-2763.

[19] Bose RK, Srinivivasachary V. Policies to Reduce Energy Use and Environmental Emissions in the Transport Sector: A Case of Delhi City. Energy Policy. 1997;25(1415): $1137-1150$

[20] Shabbir R, Ahmad SS. Monitoring Urban Transport Air Pollution and Energy Demand in Rawalpindi and Islamabad Using Leap Model. Energy. 2010;35: 2323-2332.

[21] Bașkan O, Haldenbilen S, Ceylan H, Ceylan H. Estimating Transportation Energy Demand Using Ant Colony Optimization. Energy Sources. 2015;7(2): 188-199.

[22] Zhang M, Mu H, Li G, Ning Y. Forecasting the Transport Energy Demand Based on PLSR Method in China. Energy. 2009;34(9): 1396-1400.

[23] Sönmez M, Akgüngör AP, Bektaș S. Estimating Transportation Energy Demand in Turkey Using the Artificial 
Bee Colony Algorithm. Energy. 2017;122: 301-310.

[24] Gonzalez PA, Zamarreno, JM. Prediction of Hourly Energy Consumption in Buildings Based on a Feedback Artificial Neural Network. Energy and Buildings. 2005;37: 595-601.

[25] Kalogirou S, Bojic M. Artificial Neural Networks for the Prediction of the Energy Consumption of a Passive So- lar Building. Energy. 2000;25(5): 479-491.

[26] Çodur MY, Tortum A. An Artificial Neural Network Model for Highway Accident Prediction: A Case Study of Erzurum, Turkey. Promet - Traffic \& Transportation. 2015;27(3): 217-225.

[27] Wei X, Xu G, Kusiak A. Modeling and Optimization of a Chiller Plant. Energy. 2014;73:898-907. 